\title{
Development of Malnutrition Early Detection Application in Toddlers based on Geographic Information System
}

\author{
Dony Setiawan Hendyca Putra ${ }^{1}$, I Gede Wiryawan, ${ }^{2, *}$, Estin Roso Pristiwaningsih ${ }^{3}$ \\ Ely Mulyadi ${ }^{4}$, Prawidya Destarianto ${ }^{5}$, Khafidurrohman Agustianto ${ }^{6}$
}

\author{
${ }^{1}$ Health Department, Politeknik Negeri Jember, Indonesia \\ 2, 4, 5, 6 Information Technology Department, Politeknik Negeri Jember, Indonesia \\ ${ }^{3}$ Agribusiness Management, Politeknik Negeri Jember, Indonesia \\ *Corresponding author. Email: wiryawan@polije.ac.id
}

\begin{abstract}
The decrease in the percentage of children under five who experience stunting in Indonesia did not meet the minimum standards set by the World Health Organization. Jember Regency had a proportion value of concise nutritional status (malnutrition) which was still higher than the average value of other regencies in East Java Province. The technology proposed in this study is developing technology in geographic information systems to detect malnutrition in toddlers. The design sprint and scrum methods were used as the method of software development. The detection of malnutrition was known by calculating the z-score values of the toddler's weight and height. The implementation results were evaluated using two test methods, namely Blackbox Testing and User Acceptance Testing (UAT). The result of this study is a system that can visualize stunting cases that occur in the form of geographic maps. At the same time, the evaluation results of this system obtained a value of 4.47 based on aspects or criteria related to the users of this application. The implementation of a method in the classification of stunting data can be considered as future system development.
\end{abstract}

Keywords: Malnutrition detection application, Toddlers, Geographic information system.

\section{INTRODUCTION}

Child growth below the standard is a problem that is one of the Sustainable Development Goals (SDGs) indicators, which must be resolved by 2030 . The target of the SDGs indicator in question is the end of all forms of malnutrition or known as malnutrition. The importance of the target indicator has also been described in the metadata document of the target indicator, and one of them is that chronic or recurrent malnutrition (stunting) can fail to achieve the physical and cognitive potential of children [1]. Based on malnutrition data in 2018, 52 million children under five years of age were wasted, 17 million children were severely wasted, and 155 million children were stunted [2].

The Indonesian government is severe in solving the problem of malnutrition in children under five years old.
It is stated in the social development pillar document, where height data in primary health research becomes an analysis for each child's nutritional status and height under five years of age. It was converted into a standardized Z-score value using standard anthropometric values for children-under five years set by the World Health Organization [3]. The stunting reduction target that Indonesia must achieve is the stunting prevalence rate in children under five years old, which is 14 per cent in 2024 [4], so that the decrease in this number can be taken into consideration to achieve the target in 2024. Nevertheless, the decrease in the percentage of children under five who experience stunting in Indonesia did not meet the minimum standards set by the World Health Organization.

Stunting in the province of East Java is shown in the 2018 national basic health research report, where the prevalence rate of malnutrition in the province is 3.3 
percent [5]. The prevalence rate is indeed lower than the national average of 3.9 per cent. Meanwhile, Jember Regency had a proportion value of concise nutritional status (malnutrition) which was still higher than the average value of other regencies in East Java Province. In 2020 in the Jember district, the prevalence of malnutrition was 37.94 . This value is the third-highest prevalence of malnutrition compared to other districts in the province of East Java [6].

Applications with spatial or geographic map interfaces had been widely used as an alternative in displaying data from various sectors. One example is in the socio-economic field, a study that discusses the potential of geographic information systems for the refugee crisis in efforts to relocate refugees in urban areas [7]. In applying the system, an explicit-spatial approach was adopted using several key variables in the socio-economic field so that it can be understood further about the optimal micro-spatial location for refugees [7]. An example of the following study is the application of geographic information systems in determining the socio-economic characteristics of the elderly [8]. The purpose of this study is to explore the socio-economic indicators that affect the health level of the elderly.

Many data from the health sector have also been integrated with spatial map data. A paper that discusses spatial heterogeneity and the factors that influence stunting is one of them. This paper aims to assist the government in reshaping and redesigning new interventions to reduce stunting in children under five years old [9]. Spatial heterogeneity was explored using spatial and multilevel logistic regression analysis. Then individual and household-level factors related to stunting and severe stunting were also identified using the same analysis method.

The following study that integrates data in the health sector with spatial map data is a study that presents a spatial analysis of the dengue fever outbreak using a geographic information system. The analysis carried out in this study was using Moran's I, Average Nearest Neighbor (ANN), Kernel Density Estimation (KDE) and buffer analysis with geographic information systems [10]. The purpose of this study is to map the spread of dengue outbreaks by making a risk map, and areas with high risk are identified with the risk map using geographic information systems tools.

Spatial map displays that are used specifically to show stunting events have previously been widely developed. The first is a study that studies the spatial pattern of malnutrition cases. The background of the study is malnutrition which is a significant challenge to the public health system. Therefore, this study aimed to study the spatial pattern of malnutrition cases using geographic information systems [11].
Based on the problems described previously, it is proposed an application for early detection of malnutrition with a spatial map-based display of several sub-districts in Jember Regency in this study. Before this study was conducted, a preliminary study was conducted regarding the anthropometric conditions of pregnant women related to their effect on the incidence of stunting [12]. The purpose of this study was to reduce the number of cases of malnutrition that occurred. The difference between this study and other studies that also integrate data in the health sector with previous spatial map data is in applying the $\mathrm{z}$-score calculation in detecting cases of malnutrition that occur.

\section{RELATED WORKS}

Several studies are related to this previous study. These studies also integrated data from cases of malnutrition or stunting with spatial map data. Reference [9] identified problems according to the location and risk factors for stunting in infants under five years of age. A total of 9,588 children aged between 0-59 months from Ethiopia were included in this study. The spatial logistic regression analysis method was used in this study to explore spatial heterogeneity and identify factors at the individual level and household level associated with stunting and severe stunting. The results of this study, among others, boys, multiple births, and anaemic children experience severe stunting due to factors at the individual level. Children of educated and malnourished, less wealthy mothers experience severe stunting due to factors at the household level. Based on these results, priority should be given to stunting hotspots for older children and anaemia, multiple births, and maternal malnutrition to reduce stunting [9].

The second is research that studies and evaluates the spatial pattern of malnutrition, which includes stunting, wasting and overweight. This study is a cross-sectional study. The data on child malnutrition used in this study is secondary data obtained from the World Health Organization from 2005 to 2016. This study shows that the prevalence of stunting, wasting, and overweight in children under five years occur accidentally and has emerged in the form of clusters. Then the results of this study also show that the standard deviation and mean centre of stunting and wasting cover most countries in Africa and Asia, the Middle East, but the standard deviation and mean centre of overweight covers more parts in all regions of the world. The spatial distribution of overweight also includes more than the spatial distribution of stunting and wasting. In conclusion, The results of this study could be the starting point for the development of appropriate malnutrition interventions and policies globally [11].

The following study intends to find out the spatial distribution of stunting in 2019 in a city on the island of 
Sumatra. The study was conducted using a quantitative descriptive method with a secondary data analysis approach. Data was collected by spatial analysis, followed by interviews and documentation using a geographic information system approach and a quantitative approach with data tabulation. The results of this spatial study show that almost all villages had stunting cases in that year, except in two villages. The study results with tabulated data show that two subdistricts have a total of more than 150 stunting cases. If based on the results of interviews, the resulting cause of stunting is due to mothers' low awareness and knowledge about the nutritional intake needed both when the child is in the womb and at the age of under five years [13].

The research study proposed in this paper has some novelty when compared to the related studies previously described. This study integrates the data on the incidence of stunting cases with spatial map data and calculates the $\mathrm{z}$-score of the condition of infants under five years of age. After obtaining the results of the $\mathrm{z}$ score calculation, this study will continue displaying the data in the form of a spatial map. The spatial map data is divided into several sections according to the number of cases of malnutrition and malnutrition that occur in the area. An early warning will appear on the spatial map data of the area when the number of cases of malnutrition exceeds a predetermined threshold.

\section{RESEARCH METHOD}

This research starts from the data collection stage. The data collected in this study is on weight and height or body length of children under five years, where weight is in kilograms, while data for height or body length is in centimetres. The child's body condition data were collected over five months, starting from January to May. This data collection stage is located in the Umbulsari sub-district, Jember regency. Then the village or sub-district areas that have been successfully obtained data include Gadingrejo, Gunungsari, Mundurejo, Sukoreno, Tanjungsari and Umbulsari. There is some data on the condition of children under five years old, whose village or sub-district origin is not known. They probably came from one of the villages or sub-districts of Paleran, Sidorejo, Tegalwangi, and Umbulrejo. At the same time, the spatial map data in this study was obtained from digital map data from other parties and is open source.

The system development methodology used in this research is the scrum model. This method was chosen because the workflow of this methodology consists of close collaboration between the master and scrum team with the product owner. The workflow has continuous iterations of software or system development [14]. The system development method using the scrum model is suitable for implementation in this study because the scrum model is a derivative of the agile methodology, which is very responsive to changes.

The system design stage is the next in this study. In this stage, it has started to design the interface design of the system that will be developed at the next stage of system development. In addition, at this stage, digitization of the spatial map data is also carried out. This digitization is adjusted to the sub-district area where this study is located and then further divided into several villages. Finally, in this stage, the system's needs to be developed are also determined-system requirements ranging from database requirements to the distribution of user access rights.

The next stage is the system development stage. This stage is carried out repeatedly and quickly with substages of sprint planning, sprint backlog, sprint automation, sprint execution, sprint review, and sprint retrospective. This development is carried out by the results of the system requirements determined at the previous design stage. At this stage of development, the sharing of user access is also considered. Users of this system are the general public, integrated service post (posyandu) officers, midwife, and chief of community health centres (puskesmas) in the Umbulsari subdistrict. If the development stage has been passed, then the next stage is the testing stage. At this stage, the system is tested by potential users. This testing stage will produce several inputs for improvements to the system so that a system or application running well will be obtained in the future. The test method is called the user acceptance testing (UAT) method.

\section{RESULTS AND DISCUSSION}

This research has gone through all the stages that have been described in the previous section of this paper. The final result of this research has also been obtained, namely in the form of an early warning application of malnutrition in children based on a geographic information system. Following the first stage, namely the data collection stage, data were obtained for 1,874 children under five years who visited the integrated service post (posyandu) in the Umbulsari sub-district for five months. This data becomes raw data that will be displayed in the form of a spatial map.

The second stage is the design stage, wherein a system design is produced using or unified modelling language (UML). The modelling carried out is modelling with a Use Case Diagram approach, as shown in Figure 1. Figure 1 shows three users of the malnutrition early detection application, namely the chief of Puskesmas, midwife, and Posyandu officers. These three users have associations with the features contained in the malnutrition early detection application. These features include entering data on children under five years old for midwives and Posyandu officers. The 
chief of Puskesmas can use user management features and warnings of malnutrition cases based on location. Midwives can also access the latter feature. The use case diagram also shows that the application automatically obtains spatial location data, calculates the Z-score value based on data input results for children under five years old, and then validates it.

The next stage is the application development stage using the scrum approach. This stage was successfully carried out, more than ten iterations, after consulting with the midwife and also the chief of the Puskesmas. In implementing this stage, an application has been produced that is ready to be tested on Posyandu officers. Figures 2 and 3 below show the form application's display results that are ready to be tested in the next stage. The form contains data on the weight and height of children under five years of age and how to measure their height.

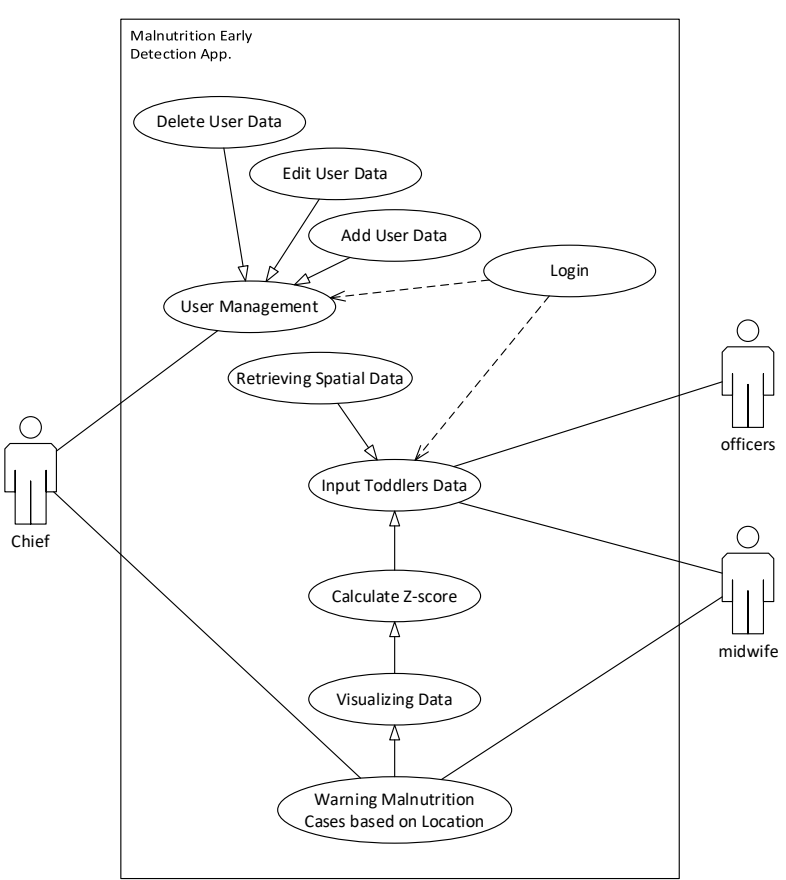

Figure 1 Use Case Diagram of the Application
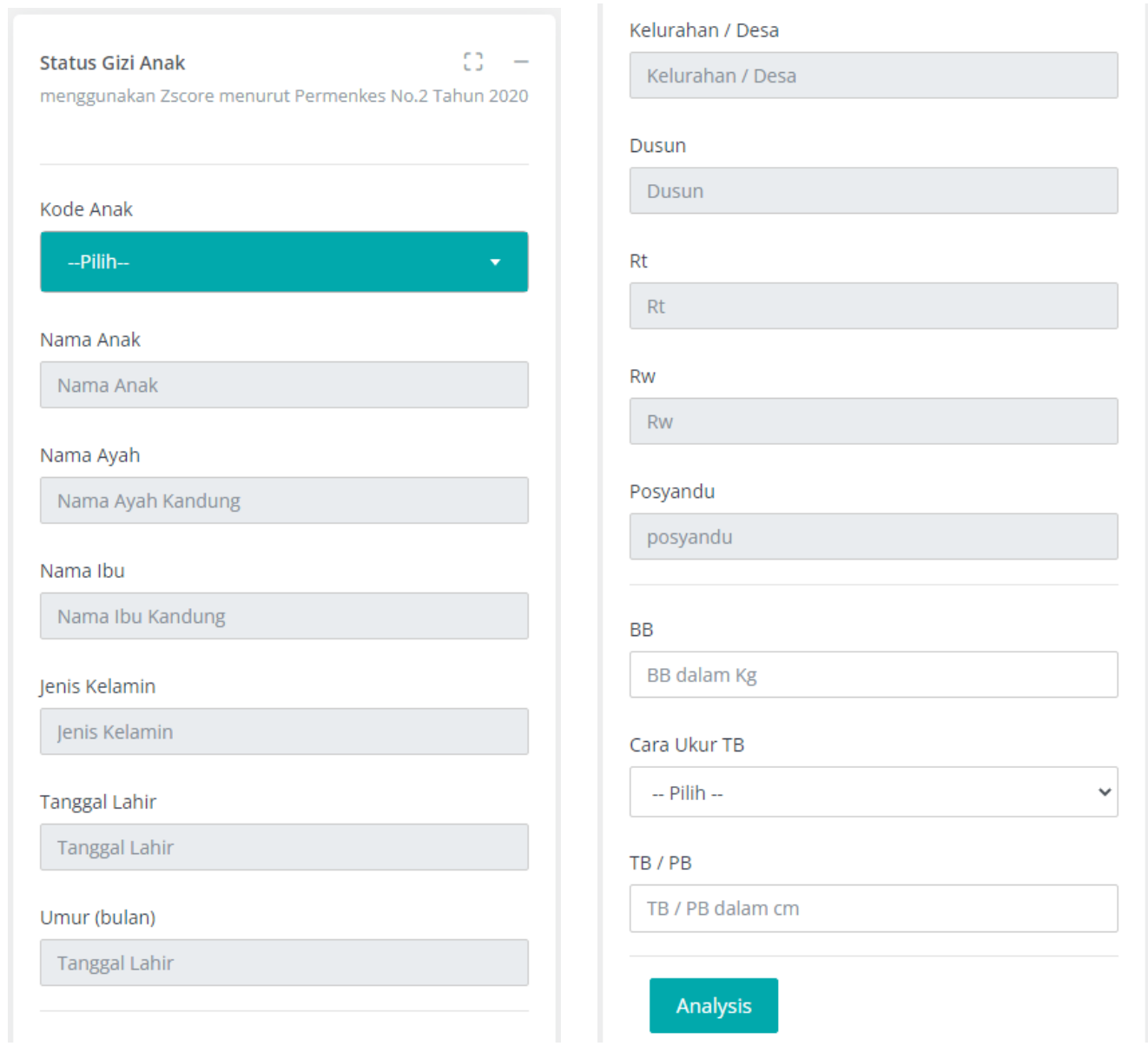

Figure 2 Z-score analysis form 

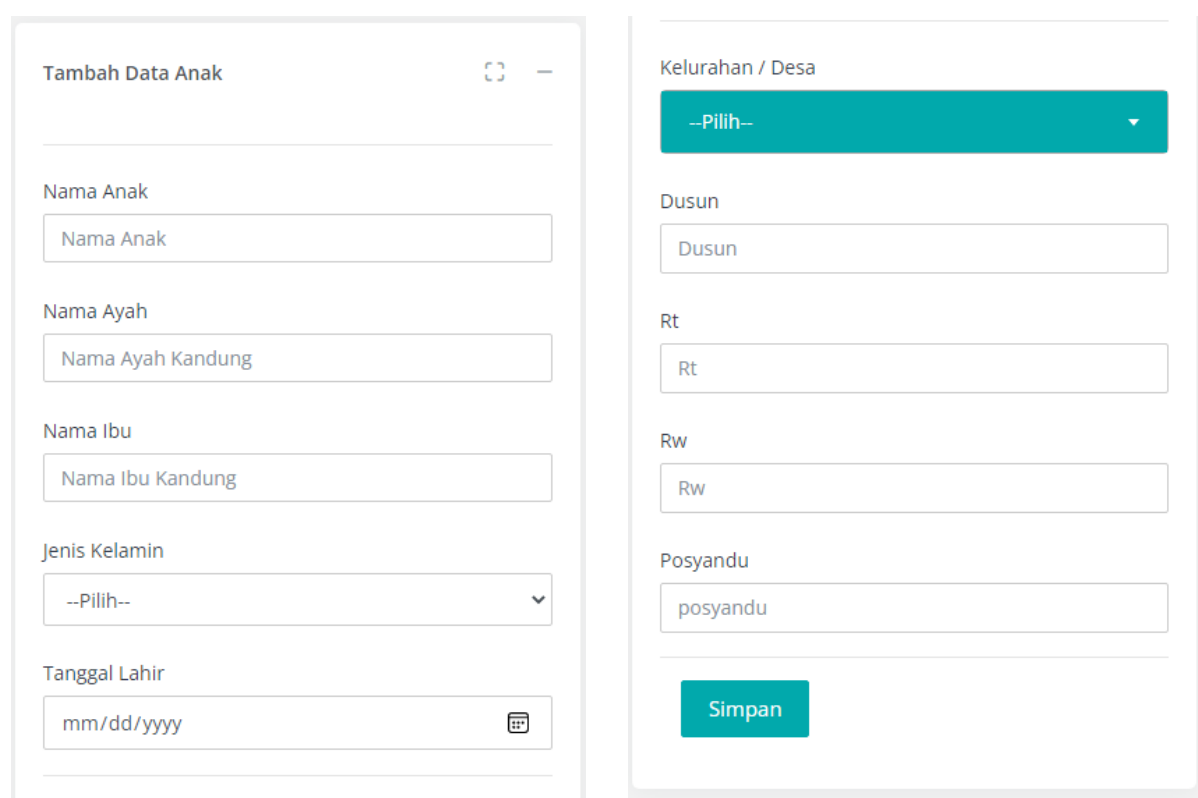

Figure 3 Add children data form

Table 1. Data from the system

\begin{tabular}{|l|c|l|l|l|l|l|l|l|l|}
\hline W & A & H & BMl & W/A & H/A & W/H & BMl/A & \multicolumn{1}{|c|}{ W/A } & H/A \\
\hline 9 & 25 & 75.5 & 15.789 & -2.429 & -4.032 & -1 & -0.176 & Under weight & Very Stunted \\
\hline 9 & 25 & 75 & 16 & -2.429 & -4.194 & -0.857 & 0 & Under weight & Very Stunted \\
\hline 10 & 25 & 80 & 15.625 & -1.714 & -2.581 & -0.667 & -0.313 & Normal Weight & Stunted \\
\hline 9 & 25 & 75.5 & 15.789 & -2.429 & -4.032 & -1 & -0.176 & Under weight & Very Stunted \\
\hline
\end{tabular}

Table 1 above shows the data needed and the data generated from the application of early detection of malnutrition. The table is obtained from the worksheet file format results exported directly from the application. The data generated from the application include data on weight for age (W/A), height for age $(\mathrm{H} / \mathrm{A})$, and data on weight for height $(\mathrm{W} / \mathrm{H})$. Finally, there is also data on body mass index for age (IMT/U) used to compare weight data for height.

The table's contents show the results of calculations that produce a comparison of the baby's weight and age with the baby's height and age. The results show a correlation between the weight and age of babies

Table 2. Result of UAT

\begin{tabular}{|c|c|c|c|c|c|c|c|}
\hline \multirow[b]{2}{*}{ Aspect } & \multicolumn{5}{|c|}{ Result } & \multirow{2}{*}{$\begin{array}{c}\text { Total } \\
\text { Responden }\end{array}$} & \multirow[b]{2}{*}{ Average } \\
\hline & $\begin{array}{l}\text { Strongly } \\
\text { disagree }\end{array}$ & Disagree & $\begin{array}{l}\text { Neither agree } \\
\text { nor disagree }\end{array}$ & Agree & $\begin{array}{l}\text { Strongly } \\
\text { agree }\end{array}$ & & \\
\hline Concept & 0 & 0 & 4 & 8 & 23 & 35 & 4.54 \\
\hline Usefulness & 0 & 0 & 5 & 6 & 24 & 35 & 4.54 \\
\hline Accuracy & 0 & 0 & 9 & 8 & 18 & 35 & 4.26 \\
\hline Performance & 0 & 0 & 7 & 7 & 21 & 35 & 4.40 \\
\hline Friendliness & 0 & 0 & 3 & 8 & 24 & 35 & 4.60 \\
\hline
\end{tabular}

Table 1 above is obtained from interviews conducted with the chief of Puskesmas, midwife, and Posyandu officers. Interviews were conducted concurrently with underweight with a ratio of height and age of very stunted toodlers. So that all of these calculations are by the calculation of the $\mathrm{z}$-score.

Furthermore, in the testing phase, the first is testing by users of Posyandu officers. This test is carried out using two methods and the first is the user acceptance testing (UAT) method, and the second is the BlackBox method. The UAT method is carried out to determine how far the user's understanding in using the application [15][16]. The UAT method in this test is carried out with several aspect as indicators. The result is shown in Table 1 below.
Posyandu officers conducting a trial of the application. Several aspects are the subject of questions in the interview, including the application concept, application 
usefulness, application's performance on processing data, application accuracy, application's UI friendliness, or the ease of using the application. The total number of participants was 35 people. Finally, it obtained a value of 4.47 on average. The aspect that needs more attention to be improved in the future is the accuracy aspect of the location point. It is because this aspect gets the lowest score, which is 4.26 .

Blackbox testing was done to determine the level of the feature's functionality [17]. These have been provided in the application. This test involves all three types of users of the application. Testing this application is that almost all features run well. It contains testing of three scenarios which are the main features in the development of this application. The first is the login feature to ensure security and share access rights to data from the application. Second, the data collection feature of children and the development of their body condition (weight, height, and age). The third is testing the scenario for calculating the $\mathrm{z}$-score, which is the basis for determining whether or not stunting occurs in children in some posyandu regions.

From the results of several stages that have been passed, an application system has been produced that can provide early detection warnings of cases of malnutrition in children under five years of age. Based on the results of the calculation of the resulting $\mathrm{z}$-score, there are an average of 24 occurrences of undernutrition and malnutrition and 19 occurrences of excess nutrition (obesity). Suppose the data on the incidence of malnutrition is integrated with spatial map data from the Umbulsari sub-district. In that case, it will obtain information on the villages with the most malnutrition incidences occurring in Umbulsari, Sukoreno, and Mundurejo. Figure 4 below shows the distribution of stunting cases in the Umbulsari Public Health Center area. The map below is displayed from Google satellite imagery.

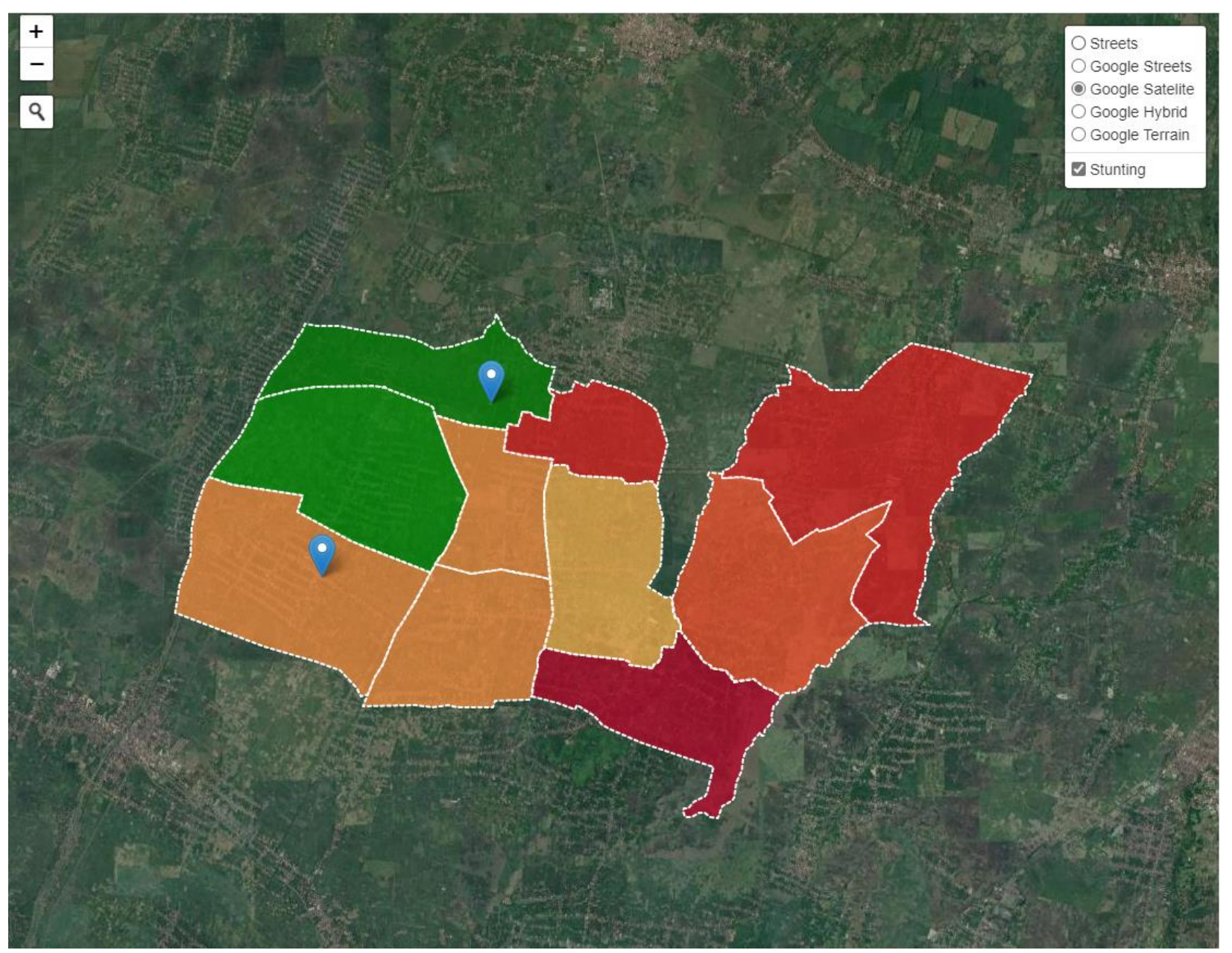

Figure 4 Map of Stunting Cases

\section{CONCLUSION}

This study proposes the integration of data on malnutrition cases that occur with spatial map data of the Umbulsari sub-district. The software development method used is the scrum approach. The results of the method are then tested using the user acceptance testing method and also BlackBox. Testing with the first 
method obtained a value of 4.58 on the Linkert scale, while BlackBox functional testing is known that all the application's main features have been running quite well.

\section{ACKNOWLEDGMENTS}

The authors would like to acknowledge the financial support of this study by grants from the PNBP of Politeknik Negeri Jember. The authors also thanked the unit of P3M and Information Technology Department, Politeknik Negeri Jember, which provided support and assistance for completing this study.

\section{REFERENCES}

[1] United Nations Statistics Division, E-Handbook on SDG Indicators. 2020.

[2] World Health Organizations, "Malnutrition 2018." https://www.who.int/news-room/fact-

sheets/detail/malnutrition (accessed Oct. 04, 2021).

[3] Bappenas, Metadata Indikator Tujuan Pembangunan Berkelanjutan (TPB)/Sustainable Development Goalls (SDGs) Indonesia Pilar Pembangunan Sosial, Edisi II. 2020.

[4] BPS, "Profil Kesehatan Ibu Dan Anak 2020," Badan Pus. Stat., vol. 53, no. 9, pp. 111-133, 2020.

[5] Kementerian Kesehatan Republik Indonesia, "Laporan Nasional Riset Kesehatan Dasar," Kementrian Kesehat. RI, pp. 1-582, 2018.

[6] Satria, "Pemkab Jember Fokus Atas Stunting," grafikanews.com,

2021. https://grafikanews.com/berita-pemkab-jemberfokus-atasi-stunting.html.

[7] E. Vaz, K. Lee, V. Moonilal, and K. Pereira, "Potential of Geographic Information Systems for Refugee Crisis: Syrian Refugee Relocation in Urban Habitats," Habitat Int., vol. 72, pp. 39-47, 2018, doi: 10.1016/j.habitatint.2017.02.001.

[8] D. Zacharias and A. Athanasios, "Monitoring of the Results through a Survey Concerning the Socio-Economic Characteristics of the Elderly Using Geographic Information Systems (GIS): A Case Study in Greece," Int. J. Innov. Econ. Dev., vol. 6, no. 3, pp. 36-45, 2020, doi: 10.18775/ijied.1849-7551-7020.2015.36.2004.

[9] B. A. Hailu, G. G. Bogale, and J. Beyene, "Spatial heterogeneity and factors influencing stunting and severe stunting among under-5 children in Ethiopia: spatial and multilevel analysis," Sci. Rep., vol. 10, no. 1, pp. 1-10, 2020, doi: 10.1038/s41598-020-73572-5.

[10] Z. A. Latif and M. H. Mohamad, "Mapping of dengue outbreak distribution using spatial statistics and geographical information system," 2015 IEEE 2nd Int. Conf. InformationScience Secur. ICISS 2015, 2016, doi: 10.1109/ICISSEC.2015.7371016.

[11] A. Almasi, A. Zangeneh, S. Saeidi, and S. R. Naderi, "Study of the Spatial Pattern of Malnutrition ( Stunting, Wasting and Overweight ) in Countries in the World Using Geographic Information System," Int. J. Pediatr., vol. 7, no. 70, pp. 10269-10281, 2019, doi: 10.22038/ijp.2019.40204.3410.

[12] I. G. Wiryawan, H. Oktava, E. Mulyadi, P. Destarianto, and K. Agustianto, "Analysis of Upper Arm Circumference Using Statistical Approach as a Risk Factor of Stunting Cases," in Proceedings of the First International Conference on Social Science, Humanity, and Public Health (ICOSHIP 2020), 2021, vol. 514, pp. 69-73, doi: 10.2991/assehr.k.210101.016.

[13] Y. Aprihatin et al., "Spatial spread of stunting incident in toddlers," vol. 17, no. 6, pp. 88728881, 2020.

[14] A. Srivastava, S. Bhardwaj, and S. Saraswat, "SCRUM Model for Agile Methodology," in 2017 IEEE International Conference on Computing, Communication and Automation (ICCCA2017), 2017, pp. 864-869, doi: 10.1109/CSEI47661.2019.8938877.

[15] G. Indrawan et al., "SIsKA: Mobile Based Academic Progress Information System," 2017, vol. 134, no. Icirad, pp. 126-130, doi: 10.2991/icirad-17.2017.24.

[16] E. Mulyadi, A. Trihariprasetya, and I. G. Wiryawan, "Penerapan Sistem Presensi Mobile dengan Menggunakan Sensor GPS (Klinik Pratama X Di Jember)," J. Nas. Pendidik. Tek. Inform. JANAPATI, vol. 9, pp. 11-20, 2020.

[17] I. G. Wiryawan, M. D. Agustiningsih, M. Yusuf, V. A. Pratama, and L. D. Wahyuningsih, "ZWaste: Aplikasi Ramah Lingkungan Berbasis Mobile," J. Resist. (Rekayasa Sist. Komputer), vol. 4, no. 1, pp. 26-32, 2021, doi: 10.31598/jurnalresistor.v4i1.664. 